\title{
Impact of a power plant cooling system on copepod and meroplankton survival (Bahía Blanca estuary, Argentina)
}

\author{
Mónica Susana Hoffmeyer, Florencia Biancalana \& Anabella Berasategui
}

Instituto Argentino de Oceanografía (CONICET-UNS), Centro Regional de Investigaciones Básicas y Aplicadas de Bahía Blanca, cc 804, Camino de la Carrindanga, Km 7,5, 8000 Bahía Blanca, Argentina. (bmhoffme@ criba.edu.ar)

\begin{abstract}
The impact of a power plant cooling system in the Bahía Blanca estuary (Argentina) on the survival of target zooplanktonic organisms (copepods and crustacean larvae) and on overall mesozooplankton abundance was evaluated over time. Mortality rates were calculated for juveniles and adults of four key species in the estuary: Acartia tonsa Dana, 1849 and Eurytemora americana Williams, 1906 (native and invading copepods), and larvae of the crab Chasmagnathus granulata Dana, 1851 and the invading cirriped Balanus glandula Darwin, 1854. Mean total mortality values were up to four times higher at the water discharge site than at intake, though for all four species, significant differences were only registered in post-capture mortality. The findings show no evidence of greater larval sensitivity. As expected, the sharpest decrease in overall mesozooplankton abundance was found in areas close to heated water discharge.
\end{abstract}

KEYWORDS. Copepods, meroplankton, estuary, cooling system, mortality.

RESUMEN. Impacto del sistema de enfriamiento de una central termoeléctrica sobre la supervivencia de copépodos y meroplancton (estuario de Bahía Blanca, Argentina). El impacto del sistema de enfriamiento de una planta termoeléctrica ubicada en el estuario de Bahía Blanca, Argentina, fue evaluado en el tiempo, sobre la supervivencia de especies zooplanctónicas seleccionadas (copépodos y larvas de crustáceos) y la abundancia general del meso-zooplancton. Se calcularon tasas de mortalidad de juveniles y adultos de cuatro especies clave en el estuario: Acartia tonsa Dana,1849 y Eurytemora americana Williams,1906 (copépodos nativo e invasor), y larvas del cangrejo Chasmagnathus granulata Dana, $1851 \mathrm{y}$ del cirripedio invasor Balanus glandula Darwin, 1854. Los valores medios hallados de la tasa de mortalidad total, fueron hasta cuatro veces más altos en la descarga que en el agua de entrada al sistema. Sin embargo sólo se registraron diferencias significativas entre estos dos sitios, en los valores de mortalidad post-captura obtenidos para las cuatro especies. Los resultados del estudio no demostraron una mayor sensibilidad larval. Como se esperaba, la disminución más pronunciada en la abundancia general del meso-zooplancton fue observada en la zona del estuario cercana de la descarga de agua sobrecalentada.

PALABRAS-CLAVE. Copépodos, meroplancton, estuario, sistema de enfriamiento, mortalidad.

The use of estuarine water in power plants for cooling purposes is common practice in a number of countries and has a major effect on water temperature in the estuary, causing depletion of the plankton and fish populations (WoLFF, 1990). This negative impact on the survival and abundance of circulating plankton and ichthyoplankton was studied during the 70 s and 80 s (Heinle, 1969; SuchaneK \& Grossman, 1971; Carpenter et al., 1974; ENRIGHT, 1977; CHOU et al., 1981) and more recently (CECCALDI, 1988; CiRoni et al., 1995; MAHYEW et al., 2000; Melton \& SeRviss, 2000) in Europe and USA. The biological effects of the damage can be seen in increased instantaneous and delayed mortality, the occurrence of synergistic processes related to toxic chemicals and a decrease in biomass (ENRIGHT, 1977; CApuzZo, 1979; HuH, 1980).

Owing to their eurythermic characteristics, zooplankton estuarine species usually display more tolerance to this type of stress than do species from other more stable marine environments. Plankton is expected to be more sensitive to thermal stress during the development stages, and meroplanktonic forms of benthic species (crabs, other crustaceans and invertebrates) are similarly expected to be less tolerant to cooling system stress factors than adults. Species react differently to the thermal stress caused by power plants in accordance with their degree of acclimation to natural temperature variations and their tolerance range. For instance, a $50 \%$ mortality rate was observed in Acartia tonsa Dana, 1849 taken in winter from Biscayne Bay, USA, when the temperature was maintained at $32{ }^{\circ} \mathrm{C}$ for $3 \mathrm{~h}$ in the laboratory (REEVE \& COSPER, 1970). In the same study, A. tonsa showed acclimation to temperatures similar to those of its natural habitat in summer and less than $25 \%$ mortality occurred when the temperature was maintained at $36^{\circ} \mathrm{C}$ for $6 \mathrm{~h}$. In a study carried out on zooplankton survival at the Anclote power plant (Florida, USA) during spring, variable survival rates for $A$. tonsa (40 to $100 \%$ ) and crab larvae (20 to $100 \%$ ) were recorded at the condenser station, where average temperatures were between 29.6 and $38.1^{\circ} \mathrm{C}$ with a difference of temperature $(\Delta \mathrm{T})$ ranging from 5.7 to $7.3^{\circ} \mathrm{C}$ (Melton \& SERVISS, 2000).

This is the first study in the region aiming to: determine the impact of the power plant cooling system on the survival response of four target species in the estuary during summer-winter conditions of 1991 and 1992; test the hypothesis of higher sensitivity of larval forms; and evaluate the impact on overall mesozooplankton abundance in areas close to and at a distance from the plant.

\section{MATERIAL AND METHODS}

Study site. The Comandante Luis Piedrabuena 
power plant (two $310 \mathrm{MW}$ turbines) is located on the Northwestern coast of the inner Bahía Blanca estuary $\left(38^{\circ} 48^{\prime} \mathrm{S}, 62^{\circ} 15^{\prime} \mathrm{W}\right)$, Argentina, to the east of Ingeniero White Port (Fig. 1). Seawater for the cooling system's condensers is obtained from the estuary at a depth of about $4 \mathrm{~m}$ and flows through the plant at a rate of around $100,000 \mathrm{~m}^{3} \mathrm{~h}^{-1}$. Difference of temperature $(\mathrm{T})$ was calculated to be $8^{\circ} \mathrm{C}$ in the plant model reference. The heated effluent is discharged into an artificial channel about $1000 \mathrm{~m}$ long, from which it flows into Napostá creek and then into the estuary. This discharge site is located approximately $2 \mathrm{~km}$ east of the cooling system's seawater intake point.

Sampling and laboratory procedures. The study was carried out from November 1990 to August 1991 and from September 1991 to August 1992, with one and two plant turbines in operation, respectively (Fig. 2). For overall zooplankton analysis, duplicate sampling was carried out by 20 vertical hauls from a depth of $4 \mathrm{~m}$ to the surface at the intake and discharge points of the cooling system. A 30-cm mouth diameter, 200- $\mu$ m mesh net was used, equipped with a mechanical flowmeter and a conventional bucket. Samples were preserved in $4 \%$ buffered formalin. All sampling was done during the day and under ebb tide conditions. Plant operating conditions were constant throughout each sampling period (with the cooling system functioning and the chlorination system not operating). Aliquots amounting to at least $25 \%$ of each sample were qualitatively and quantitatively analyzed. Two collections within a same month were sometimes performed in order to have sufficient data available. Overall mesozooplankton samples taken in coincident dates at Ing. White Port were used for the comparative analysis.

For mortality assessment, replicated live zooplankton sampling was carried out at the intake and discharge sites on the same dates as the other sampling by means of five vertical hauls using the same type of net mentioned above but, equipped with a mesh bag instead of a bucket. Samples were carefully placed in plastic jars inside an insulated box to avoid temperature changes during transportation to the lab. A staining experiment (using intra vital stain to sort live and dead specimens) was carried out immediately after each sampling to obtain mortality data, following the CARPENTER et al. (1974)'s protocol with modifications. A 31 glass beaker was pre-filled with seawater filtered through a $0.45-\mu \mathrm{m}$ mesh. A stock stain solution $(1 \mathrm{~g}$ of neutral red powder in $100 \mathrm{ml}$ of distilled water) was added to the seawater in the beaker yielding a final concentration of 1: 200,000 (Dressel et al., 1972). Each complete sample was placed in the beaker for $24 \mathrm{~h}$ at $20 \pm 1^{\circ} \mathrm{C}$, sieved thereafter through a $200-\mu \mathrm{m}$ mesh and preserved in 100 $\mathrm{ml}$ of $4 \%$ formalin, acidified by $1 \mathrm{ml}$ of a solution of $1 \mathrm{~N}$ acetic acid and $1 \mathrm{~N}$ sodium acetate in order to maintain the $\mathrm{pH}$ within neutral values.

Mortality was documented only for individuals of the four target species present in the samples. Those were females, males, and copepodid I $-\mathrm{V}$ of the native copepod A. tonsa and of Eurytemora americana

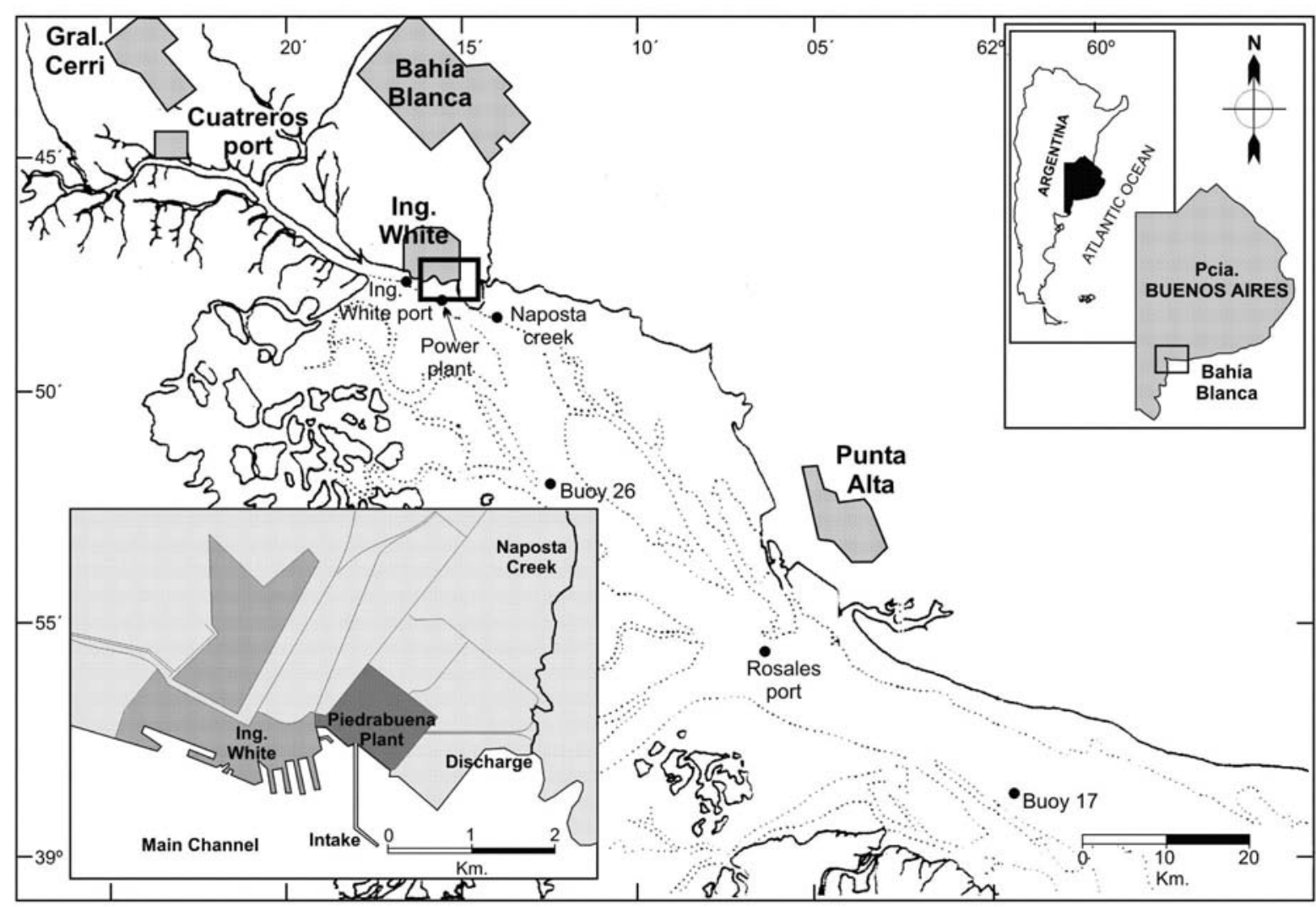

Fig. 1. Map of the inner region of Bahía Blanca estuary (Argentina) showing location and layout of the Cdte. Luis Piedrabuena power plant. 

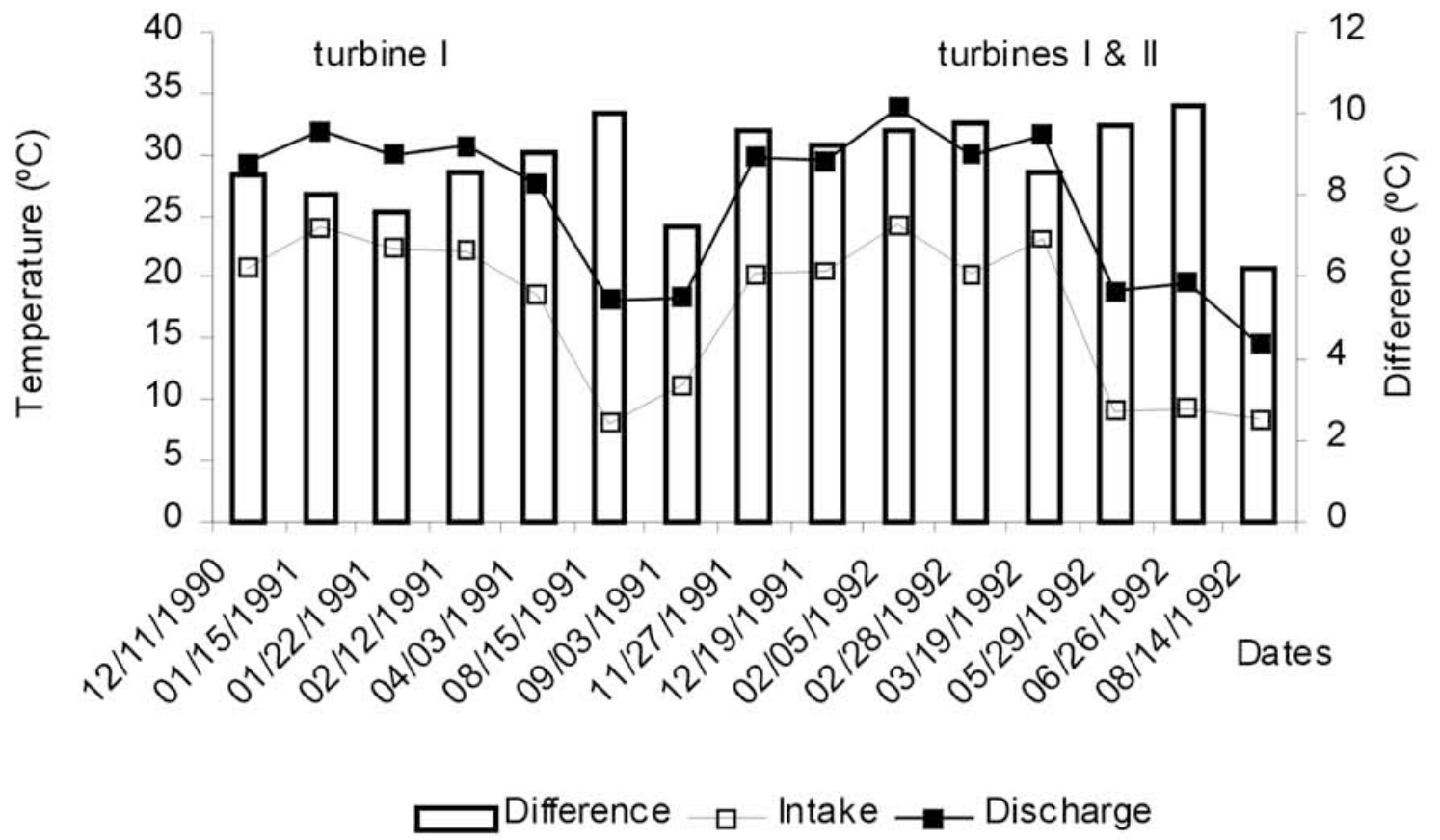

Fig. 2. Seawater temperature values $\left({ }^{\circ} \mathrm{C}\right)$ at intake and discharge points at the Cdte. Luis Piedrabuena plant and temperature difference $\left({ }^{\circ} \mathrm{C}\right)$ registered over the study period (November 1990 - August 1991 and September 1991 - August 1992) with one and two turbines operating, respectively.

Williams, 1906, an invading copepod, as well as larvae of the crab Chasmagnathus granulata Dana, 1851 and the invading cirriped Balanus glandula Darwin, 1854. These rates were recorded within a week after each experiment by sorting and counting the specimens present. Neutral red made it possible to distinguish between non-stained specimens (light and dark at transmitted light) which were those that naturally died prior to capture (pre-capture mortality); pale pink-colored ones corresponding to those which died during the 24-h experiment (post-capture mortality); and red-orange specimens, which were the survivors. Mortality of each species (stage/sex) was expressed as the percentage of its total abundance per cubic meter. Owing to the fact that the protocol applied had no standardized individual number and type, in those cases where none of the four studied species was present in the sample, relevant data was therefore lacking.

Two-way ANOVA tests were carried out for evaluating differences in pre-capture and post-capture mortality between intake and discharge, and among species (SoKal \& RohlF, 1979). In the pre-capture ANOVA, B. glandula was not taken into consideration because of the lower number and higher variance compared with the other species, whereas in the post-capture ANOVA, all species were considered. Paired t-tests were applied for testing differences between copepodids and adults of the two copepods. The other crustacean larvae could not be analyzed due to the scarcity of available data.

\section{RESULTS}

The temperature difference $(\Delta \mathrm{T})$ between intake and discharge water ranged from 6.2 to $10.2^{\circ} \mathrm{C}$ (Fig. 2).
Considering only the data interval between November and April-May for periods 1990-1991 and 1991-1992, respectively, the mean $\Delta \mathrm{T}$ was slightly lower with only one turbine in operation $\left(8.23^{\circ} \mathrm{C} \pm 0.6^{\circ} \mathrm{C}\right)$ than as from September 1991 onwards, when two were operating $\left(9.42^{\circ} \mathrm{C} \pm 0.45^{\circ} \mathrm{C}\right)$. No significant differences were found between the two periods comparing values for when one turbine was operating with those for when two turbines were operating.

Total mean mortality values found in the four considered species were up to four times higher at discharge than at intake (see the case of $E$. americana females in Fig. 3C). The highest mean total mortality at intake was registered for E. americana copepodids and at discharge, for $E$. americana copepodids. A variable percentage of this total mortality was due to pre-capture mortality which reached mean levels of around $20 \%$ and $30 \%$, at intake and discharge points, respectively (Fig. $3 \mathrm{~A})$. The highest mean pre-capture values were registered for $E$. americana males at intake and B. glandula larvae at discharge. Mean post-capture mortality for all species at intake ever was around or lower than $40 \%$, the highest values being recorded for $E$. americana copepodids, followed by $A$. tonsa females and $C$. granulata larvae (Fig. 3B). The percentage increased to about $50 \%$ at discharge, the highest values being for $E$. americana copepodids followed by $A$. tons a females and males. According to the ANOVA test results for mean precapture mortality values, there were no significant differences between sites (intake and discharge) and among species ( $A$. tonsa, E. americana and $C$. granulata larvae). ANOVA results for mean postcapture mortality similarly showed no significant differences among species. However, significant 

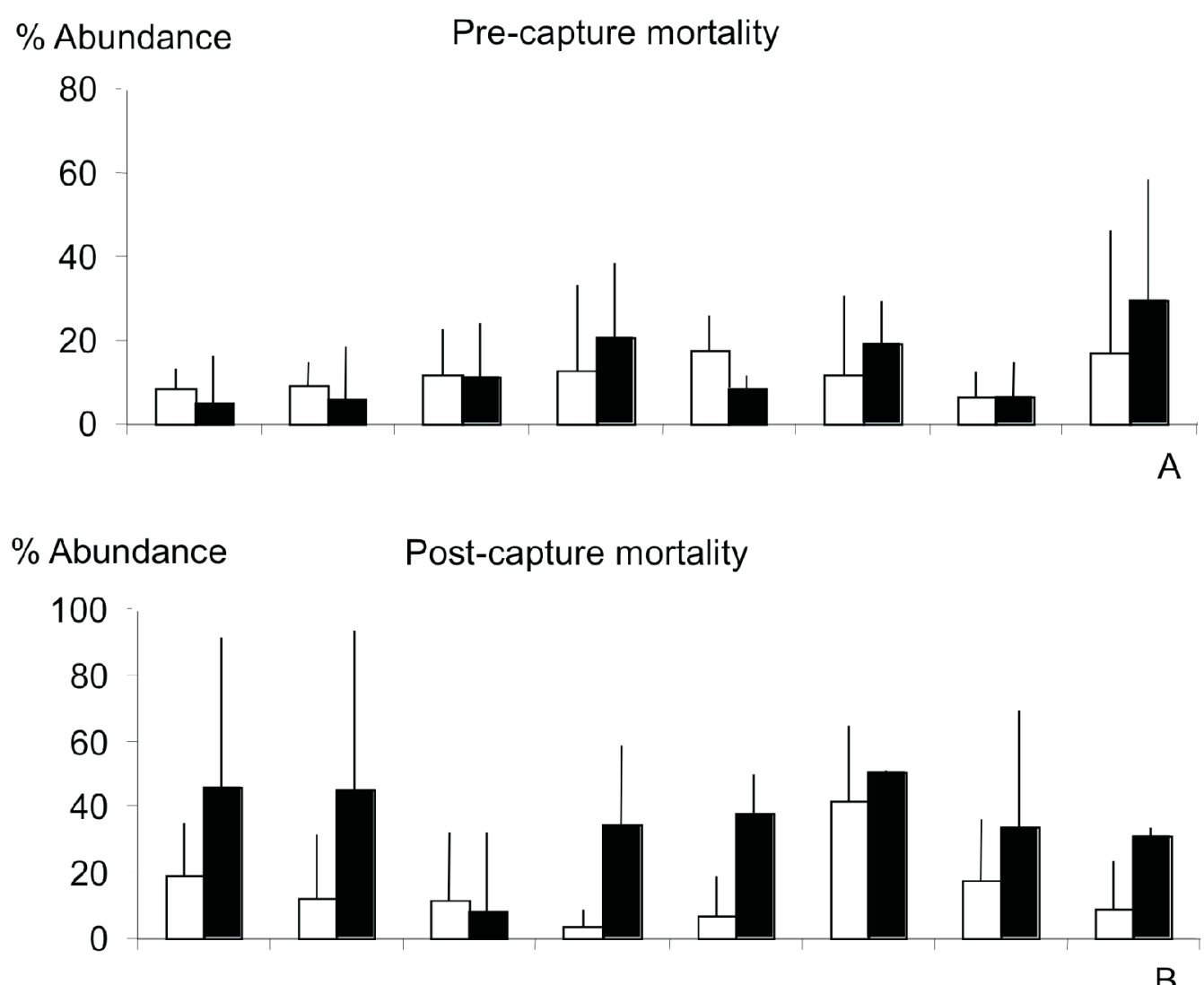

$\%$ Abundance

Total mortality

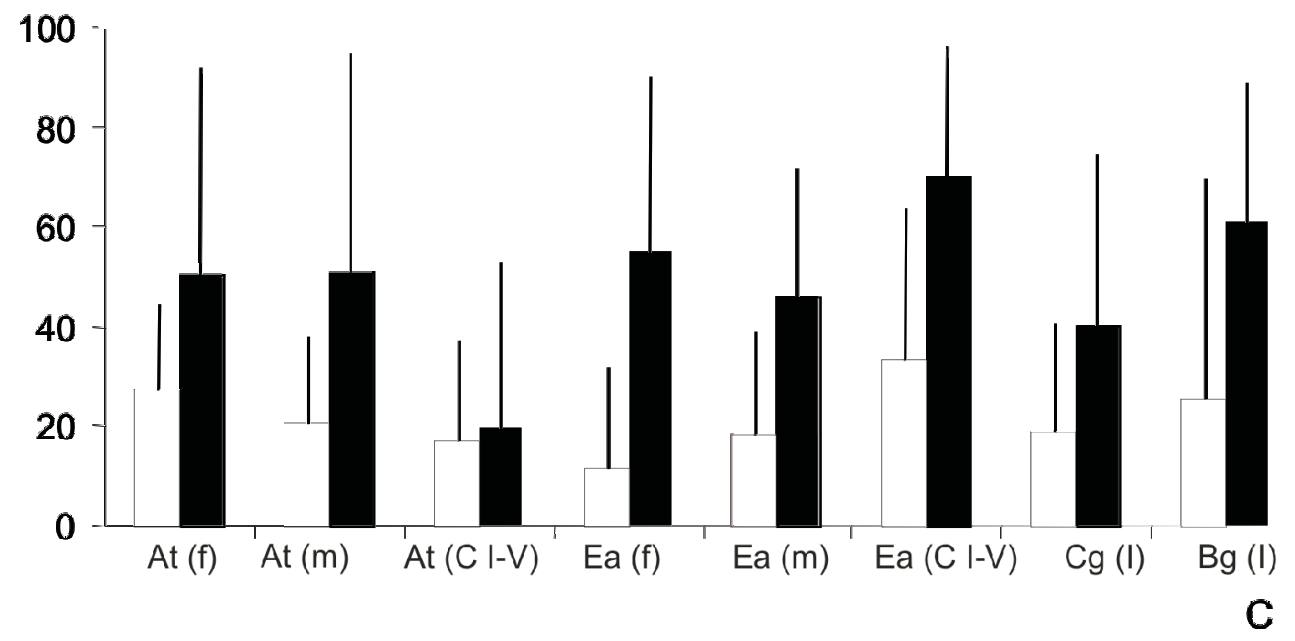

Intake Discharge

Fig. 3. Mean mortality values $(+1 \mathrm{SD})$ as a percentage of total abundance for target species (stage/sex) from intake and discharge samples. A, pre-capture mortality; B, post-capture mortality and C, total mortality (At, Acartia tonsa; Bg, Balanus glandula; Cg, Chasmagnathus granulata; Ea, Eurytemora americana; f, female; m, male; C I-V, I-V copepodids; 1, larvae).

differences were found between the intake and discharge sites $(\mathrm{p}=0.0291)$ for all species. No significant differences in total mortality data between copepod adults and copepodids were found after paired "t" tests at the discharge area. Seasonally, the highest observed total mortality values of $A$. tonsa and $C$. granulata larvae were in the middle of summer, whereas those corresponding to $E$. americana and $B$. glandula larvae were in winter (Tab. I).

The highest overall mesozooplankton abundance values were found at Ing. White Port and the lowest at the discharge area (Fig. 4). Abundance values registered at the intake area were either intermediate or as low as those observed at the discharge area. 


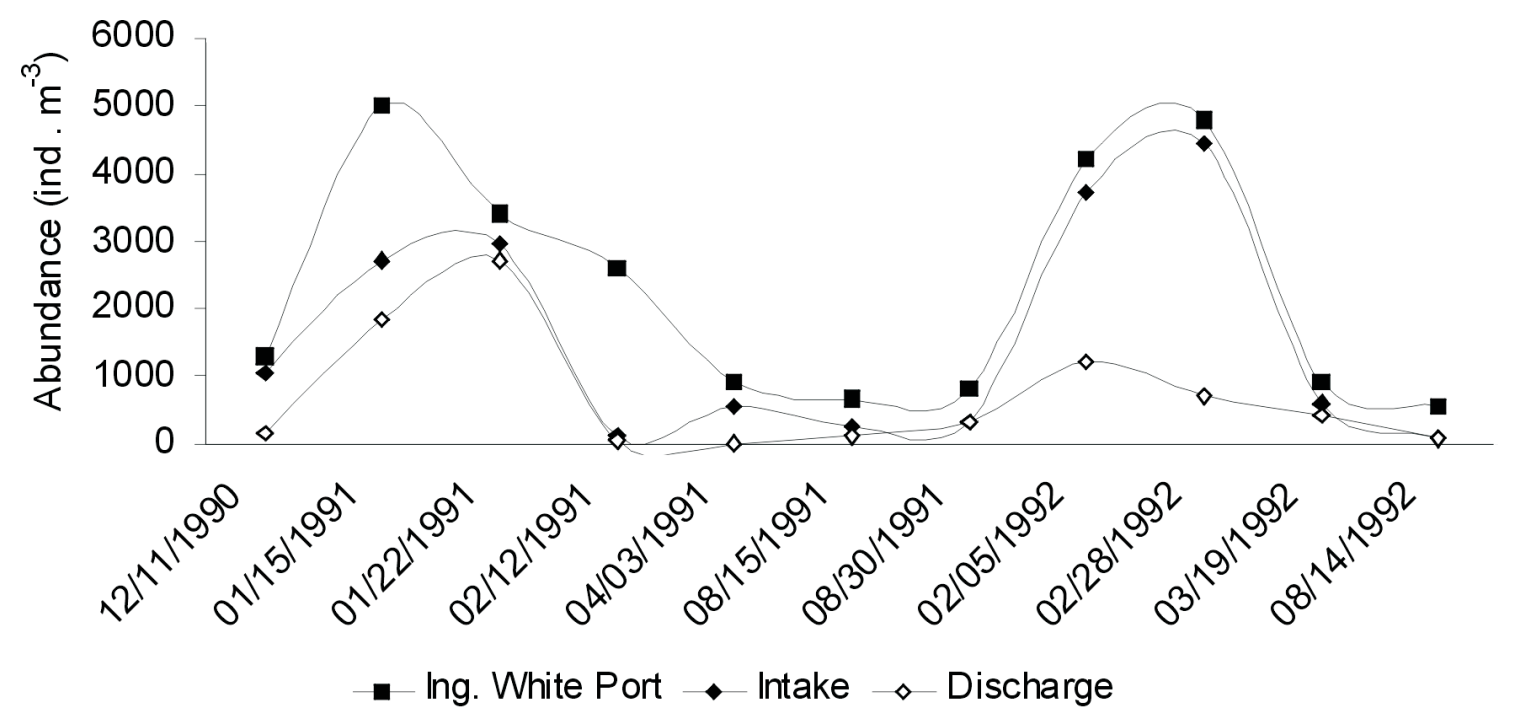

Fig. 4. Mesozooplankton abundance variation at the seawater intake site, Napostá Creek outlet and Ing. White Port areas, at several dates along the study period.

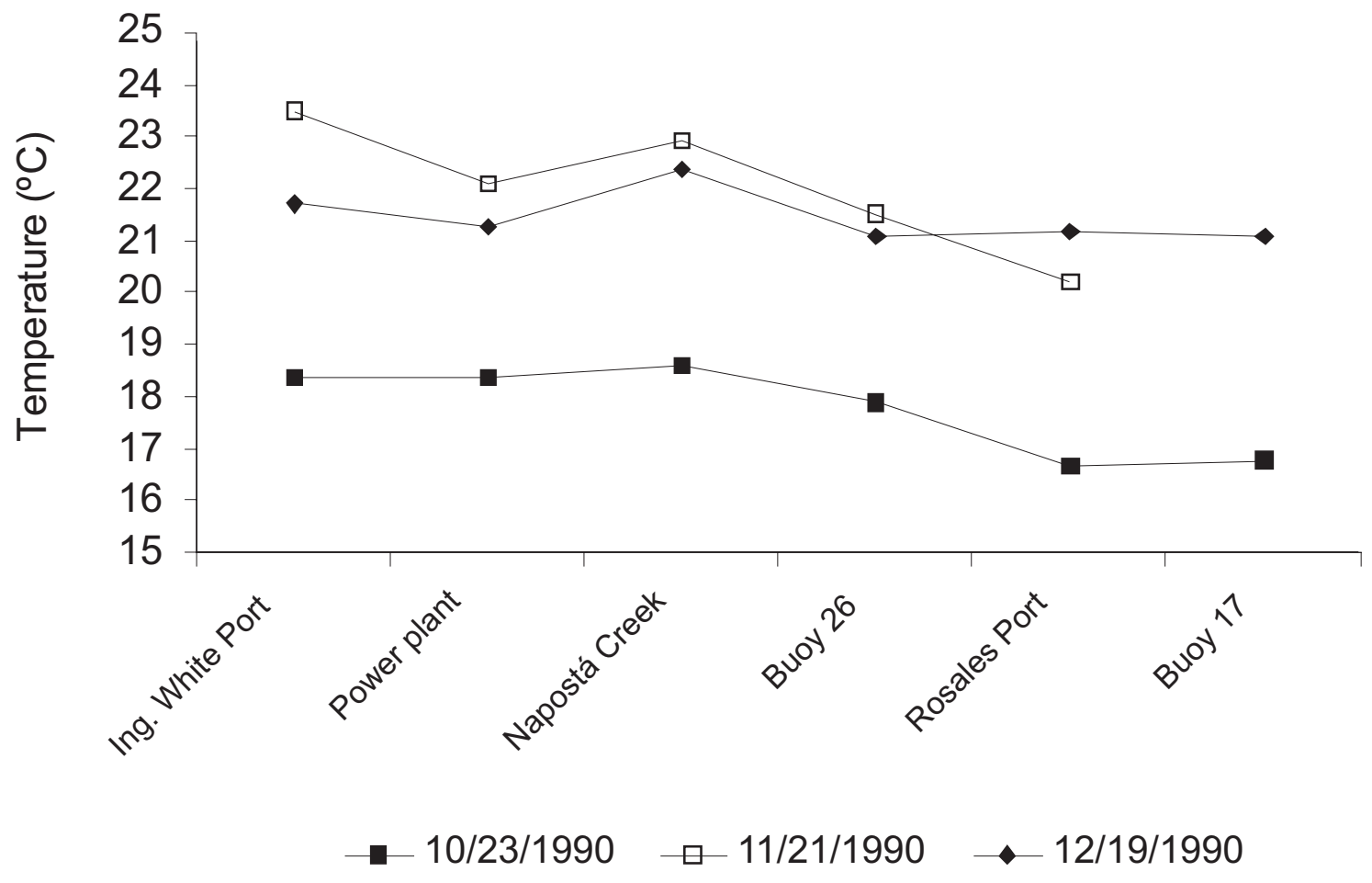

Fig. 5. Estuarine surface water temperatures at six sites, including the area in front of the Cdte. Luis Piedrabuena power plant and Ing. White Port, along the main channel of the Bahía Blanca estuary, from October to December 1990. Sites located from the estuary head to mouth, shown from left to right.

\section{DISCUSSION}

The heated seawater effluent flows into the estuary through the Napostá Creek outlet (Fig. 1) and the surface temperature of the receiving waters at the outlet and areas around the main channel are about $1^{\circ} \mathrm{C}$ below those recorded at the discharge area (pers. observ.). Turbulence caused by wind and tidal action throughout this inner estuary area (PícCOLO \& PeRILLO, 1990) probably plays a major role in temperature dissipation. Temperature data corresponding to another project (M. S. Hoffmeyer, unpubl. data), registered along the estuary main channel (Figs. 1, 5), corroborate this trend. Only a $1-2^{\circ} \mathrm{C}$ increase over natural temperatures within $\sim 2-4 \mathrm{~km}$ up and down Napostá Creek outlet were recorded from October to December 1990. These values were lower than the 
Table I. Higher total mortality mean values (from two replicates) obtained for target species (stage/sex) from intake and discharge during the study period. Number 0 indicates no mortality and (-) no occurrence of the species (stage/sex).

\begin{tabular}{|c|c|c|c|c|c|c|c|}
\hline & $01 / 15 / 1991$ & $01 / 22 / 1991$ & 08/15/1991 & 08/30/1991 & $02 / 05 / 92$ & 03/19/1992 & 08/14/1992 \\
\hline \multicolumn{8}{|l|}{ INTAKE } \\
\hline A. tonsa (fem) & 41.52 & 39.33 & 0 & - & 17.32 & 36.9 & - \\
\hline A. tonsa (male) & 50 & 33.33 & 0 & - & 15.49 & 30 & - \\
\hline A. tonsa (copep) & 50 & 0 & 0 & - & 39.13 & 21 & - \\
\hline E. americana (fem) & - & - & 0 & 0 & - & - & 34.6 \\
\hline E. americana (male) & - & - & 0 & 15.07 & - & - & 40.3 \\
\hline E. americana (copep) & - & - & 0 & 100 & - & - & 59.58 \\
\hline Grapsidae (larv) & - & 0 & 0 & - & 56.36 & 22.22 & - \\
\hline B. glandula (larv) & - & - & - & 0 & - & - & 76 \\
\hline \multicolumn{8}{|l|}{ DISCHARGE } \\
\hline A. tonsa (fem) & 85.42 & 71.29 & 100 & - & 92.3 & 27.29 & - \\
\hline A. tonsa (male) & 88.1 & 68.88 & 100 & - & 100 & 12.08 & - \\
\hline A. tonsa (copep) & 0 & 0 & 0 & - & 97 & 15 & - \\
\hline E. americana (fem) & - & - & 23.63 & 47.67 & - & - & 93.3 \\
\hline E. americana (male) & - & - & 26.32 & 36.04 & - & - & 75 \\
\hline E. americana (copep) & - & - & - & 51.06 & - & - & 88.4 \\
\hline Grapsidae (larv) & 51.28 & 42.48 & - & - & 98.86 & 32.13 & - \\
\hline B. glandula (larv) & - & - & 33.33 & 58.17 & - & - & 89.77 \\
\hline
\end{tabular}

temperature range increase $\left(4-6^{\circ} \mathrm{C}\right)$ predicted by the model of this plant's thermal impact on estuarine waters (Serman \& Petroni, 1985). The highest mesozooplankton abundance at the Ing. White Port area (ca. 5,000 ind. $\mathrm{m}^{-3}$ at summer peaks) at high water confirms this trend, indicating that the site was not directly affected by power plant discharge during the study. The impact of the discharge plume was apparently restricted to a stretch of only a few $\mathrm{km}(2-3$ $\mathrm{km}$ up and down the creek) in the vicinity of the discharge outlet (Fig. 1). Overall mesozooplankton abundance values for Ing. White Port are in agreement with those reported for the same estuary inner zone for 1991 (Hoffmeyer, 1994). The decrease in mesozooplankton abundance at discharge was evidently a consequence of the following factors affecting mesozooplankton survival: the direct impact of thermal shock and mechanical damage during entraining, and the indirect impact of increases in water temperature in plume and channel areas (KERAMBRUN, 1983), in this case those areas surrounding the Napostá Creek outlet, close to the seawater intake point.

The temperature difference values ( $\mathrm{T}$ ) obtained during periods with only one or with both turbines operating were in most cases markedly higher (reaching $\left.10.2^{\circ} \mathrm{C}\right)$ than those calculated using the model $\left(8^{\circ} \mathrm{C}\right)$ of the plant. In considering these values, account should also be taken of the natural temperature variability in the environment. The highest temperatures registered at the discharge area during summer (December to March) obviously coincide with the highest natural temperatures in the estuary (for instance temperatures of around $33.8^{\circ} \mathrm{C}$ were recorded at the discharge area on February $5^{\text {th }}, 1992$ ). The estuary surface temperature can reach 25 to $26^{\circ} \mathrm{C}$ during hot summer days, causing the final temperature values at the discharge area to be as high as $34-36^{\circ} \mathrm{C}$. These values are close to or higher than the upper critical tolerance level of most marine species. For example, though A. tonsa has an exceptional eurythermic adaptation $\left(-1^{\circ} \mathrm{C}\right.$ to $\left.+32^{\circ} \mathrm{C}\right)$, enabling it to tolerate a considerable thermal stress (GonZALEs, 1974), its maximum tolerance level was surpassed during the summer period of the study. This explains the higher mortality rate of $A$. tonsa in summer, when it usually reaches maximum abundance. Chasmagnathus granulata larvae demonstrated a similar behaviour to $A$. tonsa, also peaking during spring-summer.

In the present study, the $\mathrm{T}$ of the power plant cooling system and maximum water temperatures at discharge were higher than those recorded for the Anclote power plant (MeLTon \& Serviss, 2000). This, added to the difference in latitude, differences in the natural seasonal temperature variability and in the adaptation of the species, may explain the greater impact observed on local and invading copepod species, crab and invading cirriped larvae. Mortality values at discharge were even higher than at the intake and significant differences were found in mean postcapture mortality data. Furthermore, there was a drop in overall mesozooplankton abundance related with the heating discharge in the Bahía Blanca estuary. High and also variable survival of $A$. tonsa and crab larvae found at Anclote power plant (Florida, USA) during spring (Melton \& Serviss, 2000) suggest that these species are possibly adapted in that region to a narrow range of annual temperature variability (due to the low latitude), making them more tolerant to thermal stress than their counterpart in the Bahía Blanca estuary.

Balanus glandula and E. americana, a cirriped and a calanoid copepod recently invading in the estuary (WAGNer et al., 1993; HoffMEYer, 1994; HoFFMEYER et al., 2000), showed low tolerance to stress during their planktonic pulses at the end of winter and spring, when environmental temperatures were between 8 and $19^{\circ} \mathrm{C}$. Since these species are winterspring forms, some of the high temperatures caused by the condensers were likely above their upper tolerance level. Despite their different origin, of all tested species, the copepods $A$. tonsa and $E$. americana appear to be just as sensitive to thermal 
stress as the meroplanktonic crustacean forms. Of these latter, B. glandula larvae seem to be the most sensitive. However, in the case of the two copepods, the lack of any significant difference in total mortality between copepodids and adults did not enable us to establish whether larval forms are more sensitive than adult forms.

A number of factors hinder comparison of the mortality rates reported in different studies: the different geographic location and design of the power plants involved; differences in $\Delta \mathrm{t}$, the time elapsed during passage through the condensers, and plankton characteristics. The study performed at the Millstone Plant in Long Island Sound (USA) (CARPENTER et al., 1974) was considered for comparison mainly because of the similar latitudes of the two locations (Long Island Sound, $41^{\circ} \mathrm{N}$ and Bahía Blanca estuary, $38.5^{\circ} \mathrm{S}$ ). Our results are in agreement with the reported overall loss of copepods (70-90\%) at this power plant. The higher zooplankton mortality recorded several days after passage through the plant with respect to that recorded immediately after entraining (CARPENTER et al., 1974) could also have contributed to the decrease in mesozooplankton abundance observed at the Cdte. Luis Piedrabuena Plant discharge-intake plume zone. The above results would also indicate probable negative long-term effects on the population growth trend of the studied species as well as indirect effects on all plankton structure and functioning.

Recent studies report instantaneous mortality rates lower than those reported in most papers from the 70s and 80s (Melton \& Serviss, 2000; Mahyew et al., 2000). This could be due either to the use of betterdesigned sampling tools such as the "larva table sampling", which avoids sampling damage (MAHYEW et al., 2000), or to the possibility that marine organisms are biochemically and physiologically adapted to warm water conditions (CECCALDI, 1988). Here we used the conventional sampling methods of plankton nets and vertical tows assuming minimal sampling damage.

These results demonstrate for the first time in this region two serious causes of damage to the plankton system. Firstly, instantaneous mortality (24 h) produced by thermal shock. Although the possibility was not addressed in this study, there could also be a concomitant mechanical effect. Secondly, a drop in zooplankton abundance in the area adjacent to the plant discharge produced by instantaneous mortality and a probable increase in mortality during the days following passage through the plant. The results show no evidence of greater sensitivity to shock on the part of larval forms.

The findings of the present study make evident the need for organized monitoring of the Cdte. Luis Piedrabuena plant and similar power plants and for improvements in the local legislation governing these facilities.

Acknowledgements. To P. Cervellini for her expertise in identifying the crab larvae, to R. Camina for statistical advice, and to the staff of the Instituto Argentino de Oceanografía for sampling-lab assistance. This research was partially supported by the National Research Council (CONICET) (grants PIA $\mathrm{n}^{\circ} 049 / 90$ and PEI ${ }^{\circ} 0465 / 97$ to M. Prado Figueroa and M. S. Hoffmeyer, respectively).

\section{REFERENCES}

Capuzzo, J. M. 1979. The effect of temperature toxicity of chlorinated cooling waters to marine animals - a preliminary review. Marine Pollution Bulletin 10:45-47.

Carpenter, E. J.; Peck, B. B. \& Anderson, S. J. 1974. Survival of copepods passing through a Nuclear Power station on Northeastern Long Island Sound, USA. Marine Biology 24:49-56.

Ceccaldi, H. J. 1988. Adaptation of marine organisms to warm waters. Seminar 26 November 1987. Océanis Documents Océanographiques, 14(5):539-564.

Chou, W.; Murarka, I. P. \& Brocksen, R. W. 1981. Entrainment and impingement in power plant cooling systems. Journal Water Pollution Control Federal 53:965-973.

Cironi, R.; IoAnnilli, E. \& Vitali, R. 1995. Assessment of effects of coastal power plants on marine biological resources in Italy. In: Della Croce, N.; Connell, S. \& Abel. R. eds. International Symposium on Coastal Ocean Space Utilization III. Marginal Seas: problems and opportunities. London, Spon Press. p.313-329.

Dressel, D. W.; Heinle, D. R. \& Grote, M. C. 1972. Vital staining to sort live and dead copepods. Chesapeake Science 13:190-193.

Enright, J. T. 1977. Power plants and plankton. Marine Pollution Bulletin 8:158-160.

Gonzales, J. G. 1974. Critical thermal maxima and upper lethal temperatures for the calanoid copepods Acartia tonsa and Acartia clausi. Marine Biology 27:219-223.

HeINLE, D. R. 1969. Temperature and zooplankton. Chesapeake Science 10:186-209.

Hoffmeyer, M. S. 1994. Seasonal succession of Copepoda in the Bahía Blanca estuary. Hydrobiologia 292/293:303-308.

Hoffmeyer, M. S.; Frost, B. W. \& Castro, M. B. 2000. Eurytemora americana Williams, 1906, not Eurytemora affinis (Poppe, 1880), inhabits the Bahía Blanca estuary, Argentina. Scientia Marina 64:111-113.

Huн, Н. T. 1980. Effects of thermal effluents on marine biota in coastal waters of Korea. Acta Oceanographica Taiwanica 11:1-9.

Kerambrun, P. 1983. Effects of thermal pollution on marine organisms. Océanis, Documents Oceanographiques 9:627651 .

Mahyew, D. A.; Jensen, L. D.; Hanson, D. F \& Muessig, P. A. 2000. A comparative review of entrainment survival studies at power plants in estuarine environments. Environmental Science and Policy 3:295-301.

Melton, B. R. \& Serviss, G. M. 2000. Florida Power Corporation-Anclote Power Plant Entrainment Survival of Zooplankton. Environmental Science and Policy 3(supplement 1):233-248.

Piccolo, M. C. \& Perillo, G. M. E. 1990, Physical characteristics of the Bahía Blanca estuary (Argentina). Estuarine Coastal and Shelf Science 3:303-317.

ReEve, M. R. \& Cosper, E. 1970. The acute thermal effects of heated effluents on the copepod Acartia tonsa from a subtropical bay and some problems of assessment. In: Ruivo, M. ed. FAO Technical conference on marine pollution and its effects on living resources and fishing. London, Fishing News. p 1-5.

Serman, D. D. \& Petroni, R. V. 1985. Contaminación térmica por efecto de la nueva central termoeléctrica Bahía Blanca. Ciencia y Técnica 1:31-59.

Sokal, R. R. \& Rohl., F. J. 1979. Biometría. Principios y métodos estadísticos en la investigación biológica. Madrid, H. Blume. 819 p.

Suchanek, T. H., JR. \& Grossman, C. 1971. Viability of zooplankton. In: Williams, G. C.; Mitton, J. B.; Suchanek, T. H., Jr.; Gebelein, N.; Grossman, C.; Pearce, J.; Young, J.; 
Taylor, C. E.; Mulstay, R. \& Hardy, C. D. eds. Studies on the effects of a steam-electric generating plant in the marine environment at Northport. New York, Marine Sciences Research Center of the State University of New York. p.25-37 (Technical Report, 9)

Wagner, M. J.; Hoffmeyer, M. S.; Tejera, L. A. \& Nizovoy, A. M. 1993. Variación estacional de larvas y adultos de
Balanus en el Puerto de Ingeniero White (Estuario de Bahía Blanca, Argentina). In: Jornadas Nacionales de Ciencias Del Mar, Puerto Madryn, 1991. Actas... Puerto Madryn, Universidad Nacional de la Patagonia y Centro Nacional Patagónico (CONICET). p. 79-86.

WolfF, W. J. 1990. Anthropogenic influences and management of estuaries. Limnologica 20:153-156.

Recebido em junho de 2004. Aceito em agosto de 2005. ISSN 0073-4721 Artigo disponível em: www.scielo.br/isz 